\title{
NEW POLYMORPHISMS IN REGULATORY REGION OF CAPN3 GENE WITH NO EFFECT ON GENE EXPRESSION IN BREAST MUSCLE OF BROILER CHICKENS*
}

\author{
Katarzyna Piórkowska ${ }^{1 \bullet}$, Joanna Nowak² ${ }^{2}$ Katarzyna Połtowicz ${ }^{2}$, Katarzyna Ropka-Molik \\ ${ }^{1}$ Laboratory of Genomics, ${ }^{2}$ Department of Animal Genetics and Breeding, \\ National Research Institute of Animal Production, 32-083 Balice n. Kraków, Poland \\ •Corresponding author: katarzyna.piorkowska@izoo.krakow.pl
}

\begin{abstract}
Calpains are enzymes that belong to calcium-dependent, non-lysosomal cysteine proteases. The CAPN3 gene encodes a major intracellular specific muscle protease with a high capacity for degradation of cytoskeletal and muscle fibre proteins. Therefore, they play an important role in fusion of myoblasts, proliferation, cell growth and migration. In chickens, the gene encoding for calpain 3 is localized on chromosome 5. Due to the function of encoded protein, the CAPN3 has been chosen as a candidate gene for meat quality in chickens. Consequently, the aim of our study was to identify new polymorphisms in the regulatory region of CAPN3 gene and to investigate their impact on CAPN3 transcript abundance in breast muscles. The experiment used broilers of two genetic lines: fast- and slow-growing. The polymorphisms were identified by screening with High Resolution Melting (HRM) and sequencing based on the Sanger method. The CAPN3 gene expression was conducted by using succinate dehydrogenase complex, subunit $\mathrm{A}(\mathrm{SDH} A)$ and $60 \mathrm{~S}$ ribosomal protein L4 (RPL4) genes as endogenous controls. Four new polymorphisms were found: g.322176G $>\mathrm{A}$ in promoter region (GenBank: AADN03004661.1), c.176*C $>\mathrm{T}$, c.144*G $>\mathrm{C}$ and c.137* 147 *delCAGCCCTGCTT in 3 ' UTR sequence. The new polymorphisms were identified by using restriction enzymes $S c r F I, B s I I, A c u I, H p y A V$, respectively. The frequency of polymorphisms found in 3 ' UTR region was similar in both lines. According to polymorphisms identified in 3 'UTR region the alleles with deletion, $C$ and $C\left(c .137^{*} 147^{*}\right.$ del, c. $144 * G>C$ and c.176*C $\left.>T\right)$ were rare. The polymorphism identified in the promoter region and 3 ' UTR regions changed a few binding sites for transcription factors, but did not alter any binding sites for the other important translation regulators such as miRNA. Analysis of the effect of new polymorphisms on CAPN3 gene expression showed that in fast-growing line the chickens with GG genotype according to polymorphism g.322176G $>\mathrm{A}$ in the promoter region, were characterized by the highest $C A P N 3$ transcript abundance. Other polymorphisms in 3 UTR region seem to have no effect on CAPN3 gene expression.
\end{abstract}

Key words: CAPN3, polymorphism, gene expression, promoter and 3'UTR region, broiler chicken

* This work was supported from National Research Institute of Animal Production statutory activity, research project No. 01-4.02.1. Katarzyna Piórkowska is a recipient of a fellowship from the Foundation for Polish Science. 
Calpains are enzymes which require a suitable concentration of $\mathrm{Ca}^{2+}$ for their activation. They are involved in a variety of calcium-regulated cellular processes such as signal cell proliferation and differentiation, transduction, apoptosis, membrane fusion, and platelet activation in cytoplasm (Sorimachi and Suzuki, 2001; Huang and Wang, 2001). Therefore, deregulation of their function leads to various pathological conditions such as muscle dystrophy, neuronal degeneration, Alzheimer's disease or metastasis. Calpains exist ubiquitously in organisms ranging from humans to microorganisms (Suzuki et al., 2004). They are inactive in cytosol of cells and are translocated to membrane in response to increase of cellular $\mathrm{Ca}^{2+}$ levels (Suzuki et al., 1995). The high activity of calpains increases the rate of protein degradation in muscles (Kawabe et al., 1997).

Many reports showed that polymorphisms in $C A P N 3$ gene have an effect on carcass and meat quality traits in farm animals. For example, in cattle Hou et al. (2010) observed that homozygous cows differ from heterozygous cows in carcass weight according to SNP $(\mathrm{C} \rightarrow \mathrm{T})$ found at $2546 \mathrm{bp} C A P N 3$ polymorphism. Also in beef cattle Barendse et al. (2008) discovered polymorphism CAPN3:c.1558+225G $>$ T, which was associated with tenderness. In turn, the expression of CAST, CAPN1 and CAPN3 genes was assessed in porcine longissimus dorsi muscle (LD) divergent for shear force. The highest $C A S T$ and $C A P N 3$ expression was found in LD with high shear force $(\mathrm{P}<0.2)$, which confirms a direct role for calpastatin but not for calpain 3 in pork meat tenderization (Gandolfi et al., 2011). In chickens, numerous polymorphic sites were tested for the effect on economically important traits. Chinese researchers associated the $12814 \mathrm{~T}>\mathrm{G} C A P N 3$ polymorphism with body, carcass, breast muscle and leg muscle weight (Zhang et al., 2009). They also analysed the influence of haplotype constructed of two SNPs of CAPN3 gene on chicken traits and showed its impact on eviscerated, semi-eviscerated breast muscle and leg muscle percentage $(\mathrm{P}<0.01)$. Moreover, Felício et al. (2013), who tested experimental Embrapa F2 and commercial chicken populations, observed that SNP g.15486C $>\mathrm{T}$ in CAPN3 gene was associated with thigh yield, thawing-cooking loss, and shear force. Moreover, the analysis of gene expression conducted by Zhang et al. (2012) in breast muscle showed that fast-growing commercial line is characterized by higher CAPN3 mRNA level than native local slow-growing chickens. In view of the above reports, the aim of our study was to test the regulatory parts of $C A P N 3$ gene for identification of new polymorphisms and examine their impact on $C A P N 3$ mRNA level, which could be the first step in estimation of genetic markers. Individual information of calpain activities in muscles may be used as an aid in selection for tenderness of breast muscles and growth in broiler chickens.

\section{Material and methods}

\section{Chicken population}

A total of 169 broiler chickens of two lines, fast-growing (FG) Hubbard Flex (77 chickens) and slow-growing (SG) Hubbard JA957 (92 chickens), were investigated. All chicks were hatched in a commercial poultry hatchery, from eggs obtained from 
selected parent stock farms and delivered to the experimental farm of the National Research Institute of Animal Production, located in Aleksandrowice (Poland). There were 31 and 46 pullets in the fast- and slow-growing line, respectively. The chickens were hatched on the same day and kept on deep litter under the standard environmental conditions of a poultry house. All broilers were fed ad libitum complete starter, grower and finisher diets containing 22, 20.5 and 20.5\% CP and 2990, 3130 and $3130 \mathrm{kcal} / \mathrm{kg} \mathrm{ME}$, respectively. Fast-growing chickens were maintained to 42 days of age. During this time, cockerels and pullets reached the mean body weight of 2.80 and $2.40 \mathrm{~kg}$, respectively. The chickens were slaughtered by decapitation. Broilers characterized by slower growth rate were slaughtered at 56 days of age, when the body weight approximated the mean weight attained by fast-growing chickens. During dissection, two samples of breast muscle (pectoralis superficialis) were collected into tubes with RNAlater ${ }^{\circledR}$ solution (Ambion), and two blood samples were drawn in EDTA tubes. All samples were frozen at $-20^{\circ} \mathrm{C}$. The Local Ethics Committee for Experiments with Animals in Kraków approved all experimental procedures relating to the use of live animals.

\section{Sequencing and selection of SNPs for genotyping}

DNA was extracted from whole blood samples using the Genomic Wizard Purification Kit (Promega, Madison, WI, USA) following the instructions provided in the attached protocol. To identify new polymorphisms in the regulatory regions of $C A P N 3$ gene we used High Resolution Melting (HRM) as a screening method, which was conducted on Eco Real Time PCR System (Illumina). Primers were designed based on sequence accessible in the Ensembl database (ENSGALG00000009050) using computer program Primer3 Input (version 0.4.0) (Table 1). The HRM reaction was conducted in $10 \mu \mathrm{l}$ volume by using KAPA HRM FAST PCR Kits (KAPA Biosystem) for 24 DNA samples obtained from each broiler chicken line according to attached procedure. The samples, which presented distinct melting curves, were sequenced on capillary sequencer CEQ8000 Genetic Analysis System (Beckman Coulter, Brea, CA, USA). Primers used to amplify the sequencing product were presented in Table 1. PCR sequencing was performed using GenomeLab DTCS-Quick Start Kit (Beckman Coulter) according to manufacturer's instructions. The results obtained were analysed using $\mathrm{CEQ}^{\mathrm{TM}}$ Genetic Analysis System.

The PCR-RFLP method was used to determine genotype frequencies of four detected polymorphisms for 169 broilers of two genetic lines. The restriction enzymes were selected for detection of individual mutations using NEBCutter v 2.0 and restriction digest was conducted according to attached protocols (New England BioLabs, Frankfurt, Germany) (Table 2).

\section{Gene expression analysis}

The RNA isolation was performed using TRI Reagent ${ }^{\circledR}$ (Ambion) in accordance with the method described by Chomczyński (1993). Samples were homogenized with beads using Bullet Blender24 homogenizer (Next Advance). Quantitative and qualitative evaluation of the isolated ribonucleic acid was performed on a Nanodrop2000 spectrophotometer (Thermo Scientific) and on 2\% agarose gel. The 
$0.5 \mu \mathrm{g}$ of total RNA was transcribed into cDNA at $37^{\circ} \mathrm{C}$ using a High Capacity RNAto-cDNA master mix (Applied Biosystems) according to the manufacturer's protocol.

Table 1. Primer sequences used for High Resolution Melting (HRM) analysis and for sequencing PCR of promoter and 3'UTR regions of CAPN3 gene in broiler chickens

\begin{tabular}{|c|c|c|c|}
\hline Item & Sequence of primers used for HRM & $\begin{array}{l}\text { PCR product } \\
\text { size (bp) }\end{array}$ & TA \\
\hline 5' gene flanking region & $\begin{array}{l}\text { F CAGACTGACACCCACGCTAA } \\
\text { R ATCTGGTTCAGCTCCCTGTG }\end{array}$ & 267 & $55^{\circ} \mathrm{C}$ \\
\hline 3' UTR region & $\begin{array}{l}\text { F TTCCTTCTCTTCCTCAGTGG } \\
\text { R AAATGTCCTGGAGACACTATGG } \\
\text { Sequence of primers used for PCR-sequencing }\end{array}$ & 250 & $55^{\circ} \mathrm{C}$ \\
\hline Promoter region of gene & $\begin{array}{l}\text { F GAGGTAGCCTGCAGAATCCA } \\
\text { R CATCTGGTTCAGCTCCCTGT }\end{array}$ & 612 & $54^{\circ} \mathrm{C}$ \\
\hline 3.UTR region of gene & $\begin{array}{l}\text { F TTGATTTAGGGGCATTCCAT } \\
\text { R GGTGGTAGGAGACACCTCTGA }\end{array}$ & 603 & $55^{\circ} \mathrm{C}$ \\
\hline
\end{tabular}

TA - temperature of annealing.

Table 2. Novel polymorphisms detected in regulatory region of $C A P N 3$ gene in chickens

\begin{tabular}{|c|c|c|c|c|}
\hline $\begin{array}{l}\text { Polymorphisms } \\
\text { identified }\end{array}$ & $\begin{array}{c}\text { Polymorphism } \\
\text { type }\end{array}$ & $\begin{array}{c}\text { Primers } \\
(\mathrm{PCR} \text { product size, bp) }\end{array}$ & $\begin{array}{l}\text { Restriction } \\
\text { enzyme }\end{array}$ & $\begin{array}{l}\text { Length of restriction } \\
\text { products (bp) }\end{array}$ \\
\hline g. $322176 \mathrm{G}>\mathrm{A}^{1}$ & SNP & 612 & ScrFI & $\begin{array}{l}\text { A: } 5 / 24 / 66 / 232 / 285 \\
\text { G: } 5 / 90 / 232 / 285\end{array}$ \\
\hline c. $137 * \_147 *$ del & INDEL & $239-250$ & $A c u \mathrm{I}$ & $\begin{array}{l}\text { cagccetgctt: } 76 / 174 \\
-: 239\end{array}$ \\
\hline c. $144 * \mathrm{G}>\mathrm{C}$ & SNP & 250 & HруAV & $\begin{array}{l}\text { G: } 13 / 50 / 187 \\
\text { C: } 13 / 50 / 52 / 135\end{array}$ \\
\hline c. $176^{*} \mathrm{C}>\mathrm{T}$ & SNP & 603 & $B s l \mathrm{I}$ & $\begin{array}{l}\text { T: } 392 / 208 \\
\text { C: } 603\end{array}$ \\
\hline
\end{tabular}

${ }^{1}$ Reference sequence: GenBank AADN03004661.1 The PCR-RFLP method was adapted for four single nucleotide polymorphisms.

The expression of CAPN3 in breast muscles was determined for 169 (77 of fast-growing line and 92 of slow-growing) broiler chickens. There were 46 cockerels in both lines. Primers and probes for chicken $C A P N 3$ and endogenous genes were designed and synthesized by Applied Biosystems (TaqMan ${ }^{\circledR}$ gene expression assay: CAPN3- Gg03346514_m1). As endogenous controls we used succinate dehydrogenase complex; subunit A (TaqMan ${ }^{\circledR}$ gene expression assay: SDHAGg03330760_m1) and 60S ribosomal protein L4 (TaqMan ${ }^{\circledR}$ gene expression assay: RPL4-Gg03370187_ml) genes (unpublished data). The length of amplicons was in the range 60-82nt and they were located at the junction of two exons: 2-3, 1-2 and 2-3, respectively. One multiplex reaction, consisting of primers and probes for $C A P N 3$ and $S D H A$ genes, and singleplex reaction for $R P L 4$ gene were carried out. The reactions were performed in a volume of $20 \mu \mathrm{l}$ for each sample according to the manufacturer's protocol. Reac- 
tions were performed in 3 repeats and according to the TaqMan Expression PCR Master Mix protocol: 2 initial steps at $50^{\circ} \mathrm{C}$ for $2 \mathrm{~min}$ (UNG incubation) and $95^{\circ} \mathrm{C}$ for $10 \mathrm{~min}$ (AmpliTaq Gold activation), and 40 cycles of $95^{\circ} \mathrm{C}$ for $15 \mathrm{sec}$ (denaturation) and $1 \mathrm{~min}$ at $60^{\circ} \mathrm{C}$ (annealing/extension). The relative quantification of the transcript level was performed with 7500 Real-Time PCR System by using hydrolysis probes (TaqMan ${ }^{\circledR}$ MGB) labelled with FAM. VIC and TaqMan ${ }^{\circledR}$ Gene Expression Master Mix (Applied Biosystems). The relative mRNA abundance was calculated according to Piórkowska et al. (2011). The results were analysed using Sequence Detection System software v. 2.0.6 (Applied Biosystems).

\section{Statistical analysis}

The genotype frequency of polymorphisms was estimated with Data Characteristic using SAS Enterprise 9.3 for four new SNPs in regulatory regions of CAPN3 gene. In turn, statistical analysis was performed by ANOVA (SAS Enterprise 9.3) to assess statistical differences between level of CAPN3 mRNA and various genotypes, haplotype or diplotype classes. The effects of gender and chicken line on CAPN3 gene expression were analysed in order to include or exclude them from the model. The Levene's test was used to assess the equality of variances. To estimate significances between means, Duncan and Tukey tests were used. All results were shown as means $\pm \mathrm{SD}$. Transcription factors analysis was performed using MatInspector software (Genomatrix) with the following parameters: MatInspector library - matrix family library ver. 9.0.; selected groups - core/matrix sim; general core promoter elements $(0.75 /$ Optimized $)$, vertebrates $(0.75 /$ Optimized $)$. TFSearch ver 1.3 with parameters: database - transfac matrix table, taxonomy - vertebrate (Heinemeyer et al., 1998) and rVista 2.0 using TRANSFAC professional 10.2 library (Loots and Ovcharenko, 2004). In turn, 3`UTR region analysis was conducted by RegRNA2.0 freeware (Chang et al., 2013).

\section{Results}

Four polymorphic sites were identified in the regulatory regions of the CAPN3 gene. One of them was located in promoter region g.322176G $>$ A (GenBank: AADN03004661.1) and three in 3 'UTR region: two SNP c. $176^{*} \mathrm{C}>\mathrm{T}$ and c. $144^{*} \mathrm{G}>\mathrm{C}$ and one deletion of 11-nucleotides CAGCCCTGCTT - c.137*_147*del (Figure 1). These polymorphic sites were submitted to Short Genetic Variation database (dbSNP NCBI) and they received SNP ID: g.322176G $>$ A (ss836187510), c.176*C $>$ T (ss836187515), c.137*_147*del (ss836187514), 144*G>C (ss836312080). Newly identified polymorphisms were detected by using restriction enzymes: ScrFI, AcuI, HpyAV and BbsI, respectively (Table 2).

The investigated populations were in Hardy-Weinberg equilibrium for almost all identified polymorphisms, except g.322176G $>$ A in slow-growing chickens and c. $144 * \mathrm{G}>\mathrm{C}$ in fast-growing chickens. In case of c.137*_147*del, the insertion allele 
was the major allele in both slow- and fast-growing broilers. In turn, the animals with deletion in both alleles were not present. Fast-growing line presented different genotype distribution than slow-growing line except the polymorphism detected by $A c u$ I. In slow-growing line the chickens with genotypes $\mathrm{CC}$ and $\mathrm{CC}$ according to c. $144 * \mathrm{G}>\mathrm{C}$ and c. $176^{*} \mathrm{C}>\mathrm{T}$ were absent and in $\mathrm{FG}$ line there were $3 \%$ of chickens with genotypes $\mathrm{CC}$. Moreover, in slow-growing line the broilers with AA genotype of $g .322176 \mathrm{G}>\mathrm{A}$ polymorphism were characterized by 2-fold higher frequency than in fast-growing line (Table 3).

Table 3. Genotype and allele frequency of newly discovered polymorphisms of regulatory regions of $C A P N 3$ gene in broiler chickens

\begin{tabular}{|c|c|c|c|c|}
\hline \multirow{2}{*}{\multicolumn{2}{|c|}{ Polymorphisms and genotypes }} & \multicolumn{3}{|c|}{ Genotype and allele frequency } \\
\hline & & \multirow{2}{*}{$\begin{array}{c}\text { fast-growing } \\
0.19\end{array}$} & \multirow{2}{*}{$\begin{array}{c}\text { slow-growing } \\
0.35\end{array}$} & \multirow{2}{*}{$\begin{array}{l}\text { total } \\
0.34\end{array}$} \\
\hline g. $322176 \mathrm{G}>\mathrm{A}^{1}$ & AA & & & \\
\hline \multirow[t]{5}{*}{ ScrFI } & AG & 0.48 & 0.39 & 0.47 \\
\hline & GG & 0.33 & 0.26 & 0.19 \\
\hline & Allele & & & \\
\hline & A & 0.43 & 0.55 & 0.58 \\
\hline & G & 0.57 & 0.45 & 0.42 \\
\hline HWE P-value & & 0.84 & 0.03 & \\
\hline c.137*_147*del & Del/Del & 0 & 0 & 0 \\
\hline CAGCCCTGCTT & Ins/Del Ins/ & 0.07 & 0.08 & 0.07 \\
\hline \multirow[t]{3}{*}{ AcuI } & $\begin{array}{l}\text { Ins } \\
\text { Allele }\end{array}$ & 0.93 & 0.92 & 0.93 \\
\hline & Del & 0.03 & 0.04 & 0.03 \\
\hline & Ins & 0.97 & 0.96 & 0.97 \\
\hline WE P-value & & 0.73 & 0.68 & \\
\hline \multirow{5}{*}{$\begin{array}{l}\text { c. } 144 * \mathrm{G}>\mathrm{C} \\
\text { HруAV }\end{array}$} & $\mathrm{CC}$ & 0.03 & 0 & 0.02 \\
\hline & CG & 0.09 & 0.13 & 0.11 \\
\hline & $\begin{array}{l}\text { GG } \\
\text { Allele }\end{array}$ & 0.90 & 0.87 & 0.87 \\
\hline & $\mathrm{C}$ & 0.05 & 0.06 & 0.05 \\
\hline & G & 0.95 & 0.94 & 0.95 \\
\hline \multicolumn{2}{|l|}{ HWE P-value } & 0.0004 & 0.49 & \\
\hline \multirow{5}{*}{$\begin{array}{l}\text { c. } 176^{*} \mathrm{C}>\mathrm{T} \\
\text { Bs } l \mathrm{I}\end{array}$} & $\mathrm{CC}$ & 0.03 & 0 & 0.01 \\
\hline & $\mathrm{CT}$ & 0.26 & 0.17 & 0.21 \\
\hline & $\begin{array}{l}\text { TT } \\
\text { Allele }\end{array}$ & 0.71 & 0.83 & 0.78 \\
\hline & $\mathrm{C}$ & 0.16 & 0.08 & 0.11 \\
\hline & $\mathrm{T}$ & 0.84 & 0.92 & 0.89 \\
\hline \multicolumn{2}{|l|}{ HWE P-value } & 0.74 & 0.49 & \\
\hline
\end{tabular}

Underlined - population in Hardy-Weinberg disequilibrium (HWD). ${ }^{1}$ Reference sequence: GenBank AADN03004661.1. 

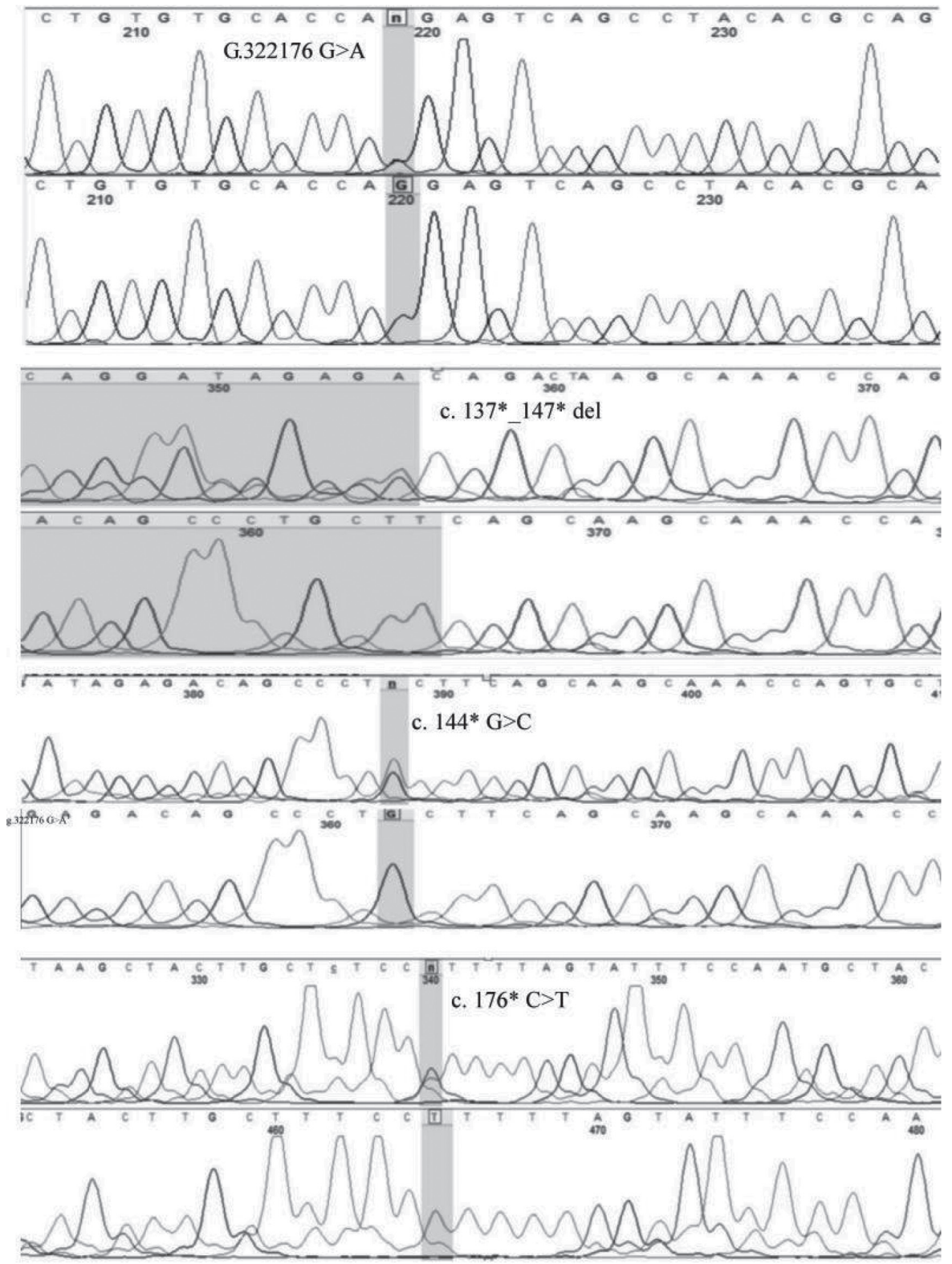

Figure 1. Chromatogram of newly discovered polymorphisms in promoter and 3 'UTR region of $C A P N 3$ gene in broiler chickens

In the investigated broilers 7 haplotypes were observed. The highest frequency was obtained for haplotype H4: A/ins/G/T (44.2\%) in FG line and for haplotype H5: $45.1 \%$ in slow-growing line. The highest differences of $8 \%$ between frequency of 
haplotypes in chicken lines were observed for haplotype H5. In turn, the diplotype analysis showed 12 different variants. Diplotype H4H5 was the most frequent in both investigated groups of chickens. Moreover, diplotype H5H5 was observed with various frequency in broiler lines: in SG with $26.1 \%$ and in FG with 9.1\% (Table 4).

Table 4. Frequency of haplotype and diplotype (\%) of polymorphisms in regulatory regions of CAPN3 gene, separately for fast- (FG) and slow-growing (SG) lines of broiler chickens

\begin{tabular}{l|c|c|c|l|c|c}
\hline \multicolumn{5}{c}{ Haplotype frequency } & \multicolumn{3}{c}{ Diplotype frequency } \\
\hline \multicolumn{3}{c}{ line } & \multicolumn{3}{c}{ line } \\
\hline & & FG & SG & & FG & SG \\
\hline H1 & $\mathrm{a} / \mathrm{ins} / \mathrm{c} / \mathrm{c}$ & 7.1 & 6.5 & $\mathrm{H} 1 \mathrm{H} 1$ & 2.6 & 0 \\
$\mathrm{H} 2$ & $\mathrm{a} / \mathrm{ins} / \mathrm{g} / \mathrm{c}$ & 7.8 & 2.2 & $\mathrm{H} 1 \mathrm{H} 4$ & 6.5 & 8.7 \\
$\mathrm{H} 3$ & $\mathrm{~g} / \mathrm{ins} / \mathrm{g} / \mathrm{c}$ & 0.6 & 0 & $\mathrm{H} 1 \mathrm{H} 5$ & 2.6 & 4.3 \\
$\mathrm{H} 4$ & $\mathrm{a} / \mathrm{ins} / \mathrm{g} / \mathrm{t}$ & $\mathbf{4 4 . 2}$ & $\mathbf{4 2 . 4}$ & $\mathrm{H} 2 \mathrm{H} 4$ & 5.2 & 1.1 \\
$\mathrm{H} 5$ & $\mathrm{~g} / \mathrm{ins} / \mathrm{g} / \mathrm{t}$ & 37 & 45.1 & $\mathrm{H} 2 \mathrm{H} 5$ & 9.1 & 3.3 \\
$\mathrm{H} 6$ & $\mathrm{a} / \mathrm{del} / \mathrm{g} / \mathrm{t}$ & 1.9 & 3.3 & $\mathrm{H} 2 \mathrm{H} 6$ & 1.3 & 0 \\
$\mathrm{H} 7$ & $\mathrm{~g} / \mathrm{del} / \mathrm{g} / \mathrm{t}$ & 1.4 & 0.5 & $\mathrm{H} 3 \mathrm{H} 5$ & 1.3 & 0 \\
& & & & $\mathrm{H} 4 \mathrm{H} 4$ & 14.3 & 18.5 \\
& & & $\mathrm{H} 4 \mathrm{H} 5$ & $\mathbf{4 2 . 9}$ & $\mathbf{3 0 . 4}$ \\
& & & $\mathrm{H} 4 \mathrm{H} 6$ & 2.6 & 6.5 \\
& & & $\mathrm{H} 4 \mathrm{H} 7$ & 2.5 & 1.1 \\
& & & $\mathrm{H} 5 \mathrm{H} 5$ & 9.1 & 26.1 \\
\hline
\end{tabular}

Bold - the highest frequency of haplotypes and diplotypes in each line, H1, H2 etc. - following haplotypes, $\mathrm{H} 1 \mathrm{H} 2$; $\mathrm{H} 2 \mathrm{H} 2$ etc. - following diplotypes, ins - insertion, del - deletion.

\section{The effect of new polymorphisms on binding transcription factors and miRNA}

The transcription factor binding analysis was performed for new polymorphisms in promoter region and 3 'UTR of chicken CAPN3 gene using three different transcription factor binding tools. The polymorphism g.322176G $>$ A did not change any sequence binding transcription factor according to MatInspector. On the other hand, TFSearch ver. 1.3 showed that this polymorphism changes the binding sequence of three transcription factors: p-300 protein, ADR1 and AP-1. The rVista 2.0 tool confirmed that this polymorphism affects binding AP-1 and p-300 protein, and also it influences loss of binding sites for SMAD4 and LFA1 transcription factors. The analysis of 3 'UTR region showed that new polymorphisms in this regulatory part of $C A P N 3$ gene did not change any binding sequence of miRNA. However, deletion of 11 nucleotides generates new motif for binding other non-coding small RNA u92788_piRNA. In addition, the SNPs in 3'UTR region change binding sequences of three transcription factors such as: Maf Recognition Elements (MARE), neuronrestrictive silencer factor (NGRE) or regulatory factor X 3 (RFX3). 


\section{The effect of genotype haplotype and diplotype on $C A P N 3$ gene expression}

For all polymorphisms the analysis of the effect on $C A P N 3$ gene expression was performed. Because the interaction between gender and line affected the level of CAPN3 mRNA (unpublished data), the analysis was conducted by taking into account the division into groups based on these factors. In our study clear influence of new polymorphisms located in the regulatory region of $C A P N 3$ gene on its expression was not observed. However, the polymorphism c. $176^{*} \mathrm{C}>\mathrm{T}$ showed some trend. The chickens with CC genotype were characterized by the highest CAPN3 expression, but there were only a few animals in the investigated group. In turn, the heterozygous chickens presented intermediate values (Figure 2).
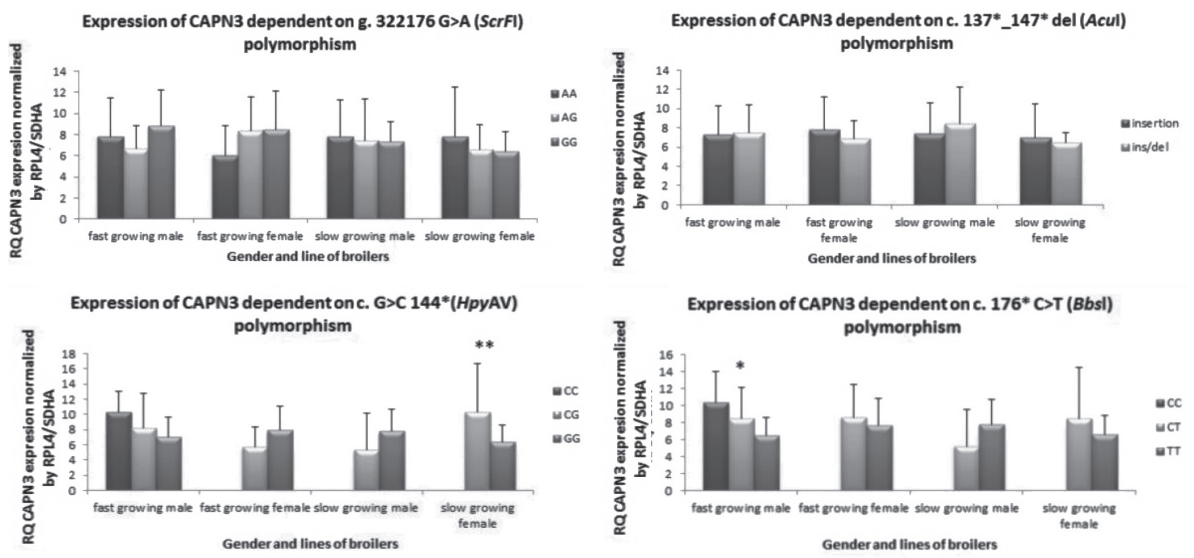

$* *=\mathrm{P}<0.01 ; *=\mathrm{P}<0.05$.

Figure 2. Expression of $C A P N 3$ gene depending on genotype of new polymorphisms in different lines and genders

Table 5. The effect of haplotype and diplotype on CAPN3 gene expression

\begin{tabular}{l|c|c|c|c|c}
\hline Haplotype & $\begin{array}{c}\text { Number copy } \\
\text { of haplotype }\end{array}$ & FG male & SG male & FG female & SG female \\
\hline H4 & 0 & $8.6 \pm 2.5$ & $7.1 \pm 2.7$ & $9.6 \pm 3.6$ & $6.4 \pm 1.9$ \\
& 1 & $6.6 \pm 3.1$ & $7.5 \pm 3.9$ & $7.9 \pm 3.0$ & $7.4 \pm 4.3$ \\
& 2 & $6.8 \pm 2.7$ & $8.4 \pm 2.5$ & $3.9 \pm 2.1$ & $6.9 \pm 2.6$ \\
H5 & 0 & $7.7 \pm 3.6$ & $7.7 \pm 3.3$ & $6.0 \pm 2.7$ & $7.8 \pm 4.7$ \\
& 1 & $7.1 \pm 2.6$ & $7.4 \pm 4.07$ & $8.5 \pm 3.2$ & $6.6 \pm 2.4$ \\
& 2 & $7.4 \pm 1.9$ & $7.3 \pm 1.9$ & $8.8 \pm 3.6$ & $6.4 \pm 1.9$ \\
H1 & 0 & $7.1 \pm 2.7$ & $7.8 \pm 3.0$ & $7.9 \pm 3.2$ & $6.4 \pm 2.2 \mathrm{~A}$ \\
& 1 & $8.2 \pm 4.6$ & $5.3 \pm 4.8$ & $5.7 \pm 2.7$ & $10.3 \pm 6.3 \mathrm{~B}$ \\
\multirow{5}{*}{ Diplotype } & H4H4 & $6.8 \pm 2.7$ & $8.4 \pm 2.5$ & $3.9 \pm 2.1 \mathrm{a}$ & $6.9 \pm 2.6$ \\
& H4H5 & $6.1 \pm 1.9$ & $7.8 \pm 4.0$ & $8.2 \pm 3.1$ & $6.6 \pm 2.4$ \\
& H5H5 & $7.4 \pm 3.6$ & $7.3 \pm 1.9$ & $8.5 \pm 3.6 \mathrm{~b}$ & $6.4 \pm 1.9$ \\
& Others & $8.5 \pm 3.5$ & $6.7 \pm 4.2$ & $7.9 \pm 3.1$ & $8.1 \pm 5.5$ \\
\hline
\end{tabular}

FG, SG - fast- and slow-growing broiler chicken lines. Values with different superscripts show significant differences between genotypes ( $\mathrm{A}, \mathrm{B}=\mathrm{P}<0.01 ; \mathrm{a}, \mathrm{b}=\mathrm{P}<0.05)$. The table includes means \pm standard deviation. $\mathrm{H} 1, \mathrm{H} 4, \mathrm{H} 5$ haplotypes with the highest frequency included in statistical analysis. 
The analyses of haplotype and diplotype did not show any significant correlation. Only in fast-growing chickens did the presence of $\mathrm{H} 4$ haplotype seem to reduce the level of CAPN3 mRNA (Table 5).

\section{Discussion}

The calpain 3 encoded by CAPN3 gene plays an important role in myofibrillar integrity (Poussard et al., 1996), which suggests its potential role in meat tenderization (Kemp et al., 2010). However, divergent results were reported. Ilian et al. (2001) showed a positive correlation between calpain 3 expression level and tenderness in sheep. Based on the fact that the highest level of CAPN3 mRNA was indicated in breast muscles of chickens characterized by the lowest shear force (unpublished data), it can be assumed that calpain 3 may be involved in chicken meat tenderization. On the other hand, Gandolfi et al. (2011), who tested CAPN3 gene expression in pigs, did not establish its involvement in the tenderization process. Moreover, the research conducted on knockout mice also did not confirm the participation of calpain 3 in post mortem proteolysis (Geesink et al., 2005). Nevertheless, the CAPN3 gene is suggested as a candidate gene for meat and carcass quality in farm animals. Therefore, the CAPN3 gene in various species was screened for identified polymorphic sites, which could become genetic markers. For example, T2546C single nucleotide polymorphism found in cattle in $C A P N 3$ gene was associated with carcass weight $(\mathrm{P}<0.05)$ (Hou et al., 2010). Felício et al. (2013) indicated that g.15486C $>$ T substitution in chicken $C A P N 3$ gene has an effect on thigh yield, thawing-cooking loss and shear force. Therefore, the aim of our study was to discover polymorphism in the regulatory region of $C A P N 3$ in broiler chickens, and to test if this polymorphism affects $C A P N 3$ gene expression.

The promoter region and 3 'UTR are regulatory parts of genes, which bind specific elements regulating transcription and translation processes. The promoter contains specific DNA sequences and response elements that provide a secure initial binding site for RNA polymerase. The transcription site start (TSS) is located in position -1 and upstream TSS in position -25 is the TATA box sequence, which is core of promoter, where TATA-binding protein (TBP) binds. Other pre-initiation transcription factors (TF) are attached successively to sequence in the nearby TATA-box, for example the $\mathrm{CpG}$ islands, which recognize sequence by Transcription Factor II B (TFIIB). In the promoter region various transcription factors are bound: enhancer or silencer of transcription, therefore the polymorphisms in promoter region may affect gene expression efficiency (Levine and Tjian, 2003). In our study, we found one single nucleotide polymorphism in the promoter region of CAPN3 gene - g.322176G $>$ A. According to some genetic tools, which could predict if the changes in DNA sequence affect binding transcription factors, this polymorphism changes unique sequence binding for p-300 protein otherwise known as EP-300. The p-300 protein regulates transcription of many genes and plays an essential role during cell growth and division, initializing maturation and differentiation of cells 
(Eckner et al., 1994). This protein is considered as a transcriptional co-activator, because it interacts with other transcription factors by binding their domains, for example: interaction domain (KIX) of CREB or MYF transcription factors (Teufel et al., 2007). Furthermore, the identified polymorphism causes changes in sequences binding two other transcription factors: zinc finger ARD1 and AP-1. However, in promoter region of $C A P N 3$ gene in broiler chickens there are other sites for ARD1. Additionally, the g.322176G $>$ A polymorphism reduces the bond of strength of AP-1 by just several percent. In turn, the changes in CAPN3 gene in 3'UTR region could also affect binding transcription factors, which are associated with localization and transport of mRNA molecule (Bertrand et al., 1998). In our study, the identified SNP ss836187515 and deletion ss836187514 in 3'UTR region of CAPN3 gene result in the loss of binding site for Maf Recognition Elements (MARE), which is related to another transcription factor, AP1 or MAF. Moreover, the ss836312080 SNP could deregulate the binding site for neuron-restrictive silencer factor (NGRE) or regulatory factor X 3 (RFX3). Nevertheless, transcription factor RFX3 is closely related to $\mathrm{X}$-box binding protein 1, which down-regulates expression of MHC class II genes, therefore the regulatory factor X probably did not work in muscle tissue.

Otherwise, the transcription factors, which are not directly associated with preparing transcription complex for polymerase RNA, could be bound by 3 'UTR region and down-regulate as enhancer or repressor of the transcription or translation processes. Therefore, polymorphisms in 3 'UTR region could change binding sequences of TFs. Moreover they could cause loss of termination codon, disorders in polyadenylation signal or influence formation of secondary structure of 3'UTR region, which affect the translation, localization and stability of the mRNA (Chatterjee and Pal, 2009). For example, ASH1 transcription factor, binding to 3'UTR region, acts as repressor of translation, because it disturbs the proper localization of mRNA (Bertrand et al., 1998). On the other hand, within the 3 'UTR region are sequence motifs recognized by other regulatory molecules such as miRNA, which base-pair with complementary sequence of 3 'UTR region, resulting in gene silencing via translational repression or target degradation (Bartel et al., 2009). Nevertheless, the bioinformatics analysis performed by using RegRNA2.0 freeware did not reveal any association between new polymorphisms and sequences binding miRNA. The same bioinformatics study reported that deletion of 11 nucleotides generates the new site to other small RNA, namely the Piwi RNA (piRNA). Nonetheless, the previous investigations reported that this molecule forms a complex with Ago3 protein and cleaved 5 UTR ends (Lin, 2007). However, studies underway continue to provide new information about the activity of non-coding RNA. Also the newly identified polymorphisms in 3'UTR region in our study could have an effect on binding undiscovered small RNA or other regulatory molecule in this way of modulating $C A P N 3$ gene expression, which might affect poultry traits.

The new polymorphisms identified in our study had no effect on the level of $C A P N 3$ gene expression in the muscle of investigated chickens. This could be due to broilers' age, because different transcription factors modulating CAPN3 gene expression could be active in chicken muscle tissues during different stages of ontogenesis. Therefore, additional investigations are necessary, which will include younger broil- 
ers. Moreover, the transcription factors could easily be modulated via posttranslational modification (PTMs) by specific modification enzyme (Everett et al., 2010) or by drugs. It was observed in human cancer therapy that $10 \%$ of all medicines are targeted on transcription factors inactivation (Gronemeyer et al., 2004). Therefore the diet could also affect chickens' gene expression and chickens used in our study have 3 other feed mixtures in various stages of ontogenesis. The second reason for lack of impact of SNP on CAPN3 expression could be the fact that binding elements in promoter region recruit a variety of cis-acting regulatory factors depending on the kind of cells or tissues, and certain transcription factors are tissue-specific (Barrett et al., 2012). Moreover, the transcription apparatus can be engaged to different types of core promoter in a developmental stage specific manner (Davuluri et al., 2008), for example hemoglobin $\gamma \mathrm{A}(H B G 1)$ gene has two promoters: TATA-box-lacking and TATA-box-containing, which are involved in $H B G 1$ gene expression during and post-embryonic development, respectively (Duan et al., 2002), and the different kind of promoter requires various transcription factors. There may be other reasons why the discovered polymorphisms had no influence on binding any regulatory factors.

In summary, the polymorphisms identified in our study did not affect CAPN3 expression examined in the muscles of fast- and slow-growing chickens. Nevertheless, the investigations correlating the new SNPs with economically important traits in poultry are necessary and will be performed in further studies, which will answer the question if the new SNPs could be useful as a tool in chicken selection directed on meat quality traits.

\section{References}

B arends e W., Harrison B.E., B unch R.J., Thom a s M.B. (2008). Variation at the calpain 3 gene is associated with meat tenderness in zebu and composite breeds of cattle. BMC Genet., 9: $41-48$.

Barrett C.W., Smith J.J., Lu L.C., Markham N., Stengel K.R., Short S.P., Zhang B., Hunt A.A., Fingleton B.M., Carnahan R.H., Engel M.E., Chen X., Beauchamp R.D., Wils on K.T., Hiebert S.W., Reynolds A.B., Williams C.S. (2012). Kaiso directs the transcriptional corepressor MTG16 to the Kaiso binding site in target promoters. PLoS One, 7(12): e51205.

B a r t e 1 D.P. (2009). MicroRNAs: target recognition and regulatory functions. Cell, 136: 215-233.

B ertrand E., Chartrand P., Schaefer M., Shenoy S.M., Singer R.H., Long R.M. (1998). Localization of ASH1mRNA particles in living yeast. Mol. Cell., 2: 437-445.

Chang T.H., Huang H.Y., Hsu J.B., Weng S.L., Horng J.T., Huang H.D. (2013). An enhanced computational platform for investigating the roles of regulatory RNA and for identifying functional RNA motifs. BMC Bioinformatics, 14 Suppl 2: S4.

$\mathrm{Ch}$ at ter j e e S., P a 1 J.K. (2009). Role of 5'- and 3'-untranslated regions of mRNAs in human diseases. Biol. Cell., 101: 251-262.

Chom czyńs ki P. (1993). A reagent for the single-step simultaneous isolation of RNA, DNA and proteins from cell and tissue samples. Biotechniques, 15: 532-537.

D a vuluri R.V., S uzuki Y., S u gan o S., Pl a s s C., H u ang T.H. (2008). The functional consequences of alternative promoter use in mammalian genomes. Trends Genet., 24: 167-177.

Duan Z.J., Fang X., Rohde A., Han H., St a mat oy annopoulos G., Li Q. (2002). Developmental specificity of recruitment of TBP to the TATA box of the human gamma-globin gene. Proc. Natl. Acad. Sci., 99: 5509-5514. 
Eckner R., Ewen M.E., New some D., Gerdes M., DeCaprio J.A., Law rence J.B., Living s to n D.M. (1994). Molecular cloning and functional analysis of the adenovirus E1A-associated $300-\mathrm{kD}$ protein $(\mathrm{p} 300)$ reveals a protein with properties of a transcriptional adaptor. Genes Dev., 8: 869-884.

Everet t L., Ha n s en M., H a n n e n ha 11 i S. (2010). Regulating the regulators: modulators of transcription factor activity. Methods Mol. Biol., 674: 297-312.

Felício A.M., Boschiero C., Balieiro J.C., Ledur M.C., Ferraz J.B., Filho M.T., Moura A.S., Coutinho L.L. (2013). Identification and association of polymorphisms in $C A P N 1$ and $C A P N 3$ candidate genes related to performance and meat quality traits in chickens. Genet. Mol. Res., 12: 472--482.

Gandolfi G., Pomponio L., Ertbjerg P., Karlsson A.H., Nanni Costa L., Lam e t s c h R., R u s s o V., D a v oli R. (2011). Investigation on CAST, CAPN1 and CAPN3 porcine gene polymorphisms and expression in relation to post-mortem calpain activity in muscle and meat quality. Meat Sci., 88: 694-700.

Ge e s in k G.H., Ta y lor R.G., K o o h m a ra i e M., (2005). Calpain 3/p94 is not involved in postmortem proteolysis. J. Anim. Sci., 83: 1646-1652.

Gron e m e ye r H., Gu s t a f s s o n J.A., L a u d e t V. (2004). Principles for modulation of the nuclear receptor superfamily. Nat. Rev. Drug Discov., 3: 950-964.

He in e meyer T., Wingender E., Reuter I., Hermjakob H., Kel A.E., Kel O.V., Ignatieva E.V., Ananko E.A., Podkolodnaya O.A., Kolpakov F.A., Podkolodny N.L., Kolchanov N.A. (1998). Databases on Transcriptional Regulation: TRANSFAC, TRRD and COMPEL. Nucleic Acids Res., 26: 364-370.

H o u G., Z en g H., Wang D.G., Huang X., X u S. (2010). Genetic variation in CAPN3 gene and its relationship with carcass traits in cattle. Chin. J. Anim. Vet. Sci., 41: 398-402

Huang Y., Wang K.K.W. (2001). The calpain family and human disease. Trends Mol. Med., 7: $355-362$.

Ilian M.A., Morton J.D., Kent M.P., Le Couteur C.E., Hickford J., Cowley R., B i c kerst a ffe R. (2001). Intermuscular variation in tenderness: Association with the ubiquitous and muscle-specific calpains. J. Anim. Sci., 79: 122-132.

Kawabe K., Maeda Y., Okamoto S., Hashiguchi T. (1997). Correlation between skeletal muscle calpain activity and fractional rate of muscle degradation of Japanese quail, Coturnix coturnix japonica. Jpn. Poultry Sci., 34: 231-239.

K e m p C.M., S e n s ky P.L., B ard s ley R.G., B u t te ry P.J., P a r r T. (2010). Tenderness - an enzymatic view. Meat Sci., 84: 248-256.

L e v in e M., T j i a n R. (2003). Transcription regulation and animal diversity. Nature, 424: 147-151.

L i n H. (2007). piRNA in Germ Line. Science, 316, p. 397.

L o ot s G., O v c hare n k o I. (2004). rVista 2.0: evolutionary analysis of transcription factor binding sites. Nucleic Acids Res., 32: 217-221.

Piórkowska K., Oczkowicz M., Różycki M., Ropka-Molik K., Piestrzyńska- K a j t o c h A. (2011). Novel porcine housekeeping genes for real-time RT-PCR experiments normalization in adipose tissue: assessment of leptin mRNA quantity in different pig breeds. Meat. Sci., 87: 191-195.

Pous sard S., Duvert M., B a l cerzak D., Ram a s s a m y S., B rust is J.J., C ott in P., Du c a staing A. (1996). Evidence for implication of muscle-specific calpain (p94) in myofibrillar integrity. Cell Growth Differ., 7: 1461-1469.

S or i m a c h i H., S u zu k i K. (2001). The structure of calpain. J. Biochem., 129: 653-664.

Suzuki K., Sorimachi H., Yoshizawa T., Kimbara K., Ishiura S. (1995). Calpain: novel family members. activation and physiological function. Biol. Chem. Hoppe Seyler., 376 : 523-529.

S uzuki K., Hat a S., K aw a b a t a Y., S or i m a c h i H. (2004). Structure, activation and biology of calpain. Diabetes, 53, Suppl. 1: 12-18.

Te u fel D.P., Fre und S.M., B y c r oft M., F e r s h t A.R. (2007). Four domains of p300 each bind tightly to a sequence spanning both transactivation subdomains of p53. Proc. Natl. Acad. Sci. USA., 104: 7009-7014.

Zhang Z.R., Li u Y.P., Ya o Y.G., Ji ang X.S., D u H.R., Zhu Q. (2009). Identification and as- 
sociation of the single nucleotide polymorphisms in calpain3 (CAPN3) gene with carcass traits in chickens. BMC Genet., 10, p. 10.

Zhang Z.R., Zhu Q., Ya o Y.G., J i a ng X.S., D u H.R., L i u Y.P. (2012). Characterization of the expression profile of calpain-3 (CAPN3) gene in chickens. Mol. Biol. Rep., 39: 3517-3521.

Received: 14 XII 2013

Accepted: 14 II 2014 